\title{
Effect of Germination on the Nutritional and Protein Profile of Australian Sweet Lupin (Lupinus angustifolius L.)
}

\author{
Rumiyati $^{1}$, Anthony P. James ${ }^{2}$, Vijay Jayasena ${ }^{2,3}$ \\ ${ }^{1}$ Faculty of Pharmacy, Gadjah Mada University, Jogyakarta, Indonesia; ${ }^{2}$ Food Science \& Technology, School of Public Health, Cur- \\ tin Health Innovation Research Institute, Curtin University of Technology, Perth, Australia; ${ }^{3}$ Centre for Food \& Genomic Medicine \\ (CFGM), Western Australian Institute for Medical Research, Perth, Australia. \\ Email: rumiyaris@ugm.ac.id
}

Received January $27^{\text {th }}, 2012$; revised March $12^{\text {th }}, 2012$; accepted March $20^{\text {th }}, 2012$

\begin{abstract}
Australian Sweet Lupin (ASL) has a nutritional profile ideally suited for human consumption with high protein and fibre, but low starch and fat content. The nutritional and protein profile of germinated ASL may be better than ungerminated ASL and these improvements would provide further benefits in its use as an ingredient in food applications. In this study the nutritional components such as protein, crude fibre, fat and protein profile of germinated ASL flour following germination at $25^{\circ} \mathrm{C}$ and $90 \%-95 \%$ relative humidity for 9 days were determined. The changes in the pattern of ASL protein during germination were analysed using sodium dodecyl sulphate-polyacrylamide gel electrophoresis (SDS-PAGE). Germination significantly increased crude fibre contents by $450 \%(\mathrm{db})$, total protein contents by $38 \%(\mathrm{db})$ and decreased the fat content by $70 \%(\mathrm{db})$ at day 9 of germination. Electrophoretic analysis of the protein fractions revealed that during germination up to 9 days, some of the high molecular weight proteins disappeared. Germination represents a means to further improve the nutritional profile of the germinated ASL flour with an increased fibre and protein, but lower fat content.
\end{abstract}

Keywords: Germination; Nutrition; Protein Profile; Australian Sweet Lupin

\section{Introduction}

Lupin is a grain legume and an important crop in Australia. It has been primarily used for animal feed and is high in protein and dietary fibre, but low in fat and starch. Due to its unique nutritional composition and health benefits, lupin could be used in various human food formulations. The comparable nutritional composition to soybean and its lower price are additional benefits for the use of lupin in the human diet [1]. Sweet lupin, in particular Australian Sweet Lupin contains lower antinutritional factors than other species of lupin [2,3]. Protein is the main macronutrient in lupin that has nutritional benefits and other important roles in food formulations due to its functional properties. Functional properties of sweet lu- pin protein isolate have been shown to be comparable with soy protein isolate which is commonly used in food formulations [4].

Germination involves sprouting of seeds at the beginning of the development of seeds into plants. Germination of legumes is often used to improve the flavour and nutritional value of legumes and to reduce the antinutritional factors [5]. Soluble protein, protein digestibility and essential amino acids of soybean, pigeon beans and peas are improved by germination [6-8]. Furthermore, regarding to protein composition during germination, subunits of conglutin $\alpha$ and $\beta$ in Lupinus albus are degraded extensively during germination, whereas conglutin $\gamma$ is not degraded [9]. In food applications, flours prepared from germinated yellow pea, lentil and faba bean have better nutritional value than the raw seeds and the flours have been applied in bread and pasta production $[10,11]$.

Chemical composition of ASL and its germinated state is known [12]. However, further information regarding the effect of germination on the nutritional profile, protein isolate and its profile in ASL is particularly lacking. This research was therefore conducted to determine the change in the nutritional components, protein isolates and the electrophoretic protein pattern of ASL following germination process. 


\section{Materials and Methods}

\subsection{Material}

ASL (Lupinus angustifolius L.) seeds were grown at Wongan Hills Research Station, Western Australia, harvested in 2005 and stored at $9^{\circ} \mathrm{C}-11^{\circ} \mathrm{C}$ until used for experiments. The seeds were supplied by the Department of Agriculture and Food, Western Australia.

\subsection{Seed Germination}

For germination, the seeds were disinfected with $0.07 \%$ sodium hypochlorite before being spread on dishes lined and then covered with moistened paper towel. The dishes were placed in an incubator set up at $25^{\circ} \mathrm{C}$ and $90 \%$ $95 \%$ humidity for $1-9$ days. The seeds were rinsed twice per day to maintain the moisture. At 1, 3, 5, 7 and 9 days of germination, a sample of the germinated seeds was taken and de-hulled. The de-hulled sprouts were dried in an oven at $50^{\circ} \mathrm{C}$, then ground using a grinder (DeLonghi, Italy) and passed through a $0.5 \mathrm{~mm}$ sieve. The flour was stored at $4^{\circ} \mathrm{C}$ until further analysis.

\subsection{Chemical Analysis}

Protein content was determined using AOAC Kjeldahl method (950.36) [13]. Oil content was determined by the AOAC method (963.15) [13] using a Buchi E-816 Soxhlet extraction unit (Switzerland). Crude fibre content was estimated using Fibercap 2021 (Foss Analytical, Denmark).

\subsection{Protein Isolation}

The procedure of fractionation consisted of alkaline extraction, followed by acid precipitation and $\mathrm{Zn}$ precipitation of soluble protein from the supernatant [14]. For alkaline extraction, defatted germinated flour was suspended in water $(1: 20 \mathrm{w} / \mathrm{v})$, then adjusted to $\mathrm{pH} 9.0$ with $0.1 \mathrm{M} \mathrm{NaOH}$ solution and stirred for $2 \mathrm{~h}$ at room temperature. The slurry was centrifuged at $4500 \mathrm{rpm}$ for 15 min and the residue (fibre) was collected. Acid precipitation was performed by addition of $0.1 \mathrm{M} \mathrm{HCl}$ solution to supernatant and $\mathrm{pH}$ reduced to $\mathrm{pH}$ 4.5. The slurry was centrifuged at $4500 \mathrm{rpm}$ for $15 \mathrm{~min}$. The precipitate was expected to consist of conglutin $\alpha, \beta$ and $\delta$. Supernatants were collected for further purification by readjusting the $\mathrm{pH}$ to 7.0 by addition of $0.1 \mathrm{M} \mathrm{NaOH}$ solution. Zinc chloride $\left(\mathrm{ZnCl}_{2}\right)$ was then added to the supernatant at a final concentration of $20 \mathrm{mM}$. Following centrifugation, the precipitate was collected (which should contain conglutin $\gamma$ ). All the precipitates were washed to $\mathrm{pH} 7.0$ with distilled water and then freeze-dried for further analyses.

\subsection{Analysis of Protein Composition Using SDS-PAGE}

NuPAGE Novex [bis (2-hydroxyethyl) amino] tris (hy- droxymethyl) methane 10\% gels, NuPAGE MES SDS running buffer, NuPAGE reducing agent, NuPAGE LDS Sample buffer and SeeBlue Plus2 prestained standard (Invitrogen, Milan, Italy) were prepared for SDS PAGE. Electrophoresis was performed using XCell SureLock Mini-Cell (Invitrogen, Milan, Italy). Prior to electrophoresis, protein samples were denatured by mixing $20 \mu \mathrm{L}$ of protein solution $(10 \mu \mathrm{g} / \mu \mathrm{L}), 25 \mu \mathrm{l}$ of NuPAGE sample buffer, $10 \mu \mathrm{L}$ of NuPAGE reducing agent and $45 \mu \mathrm{l}$ of double distilled water to a final volume of $100 \mu \mathrm{l}$. The mixture was heated at $70^{\circ} \mathrm{C}$ for $10 \mathrm{~min}$ to reduce the protein. The reduced protein samples $(10 \mu \mathrm{L})$ were loaded into the wells of the gels and electrophoresis was run at a voltage of $150 \mathrm{mV}$ for $1 \mathrm{~h}$. Once the dye front reached the bottom of the gel, the gel was stained with $0.15 \%$ Coomassie Brilliant Blue in 50\% (v/v) methanol and 7\% acetic acid. After the staining, the gels were destained with solution composed of $7 \%$ of acetic acid and $20 \%$ methanol. The molecular weights of proteins were determined by comparing molecular weights of the proteins present in the sample against the protein standards (4 $250 \mathrm{kDa}$, Sigma).

\subsection{Statistical Analysis}

Data were analysed using SPSS for Windows version 18. Differences between samples were determined using one-way ANOVA. Following Levene's homogeneity test of variance and the Tukey's post hoc tests were used to determine which samples were different. Chemical composition data which did not meet the assumption of one way ANOVA test were analysed by non parametric Kruskal-Wallis test followed by Mann-Whitney U test. A $5 \%$ level of significance was applied in the statistical tests, where P-value of less than 0.05 indicated the presence of significant differences.

\section{Result and Discussion}

\subsection{Yield of Dried De-Hulled Germinated ASL}

The weight of dried de-hulled sprouts yielded from germination of $100 \mathrm{~g}$ of seeds for periods up to 9 days are shown in Table 1. The yield on dry matter basis decreased with germination time. Following germination for 9 days, $100 \mathrm{~g}$ of ASL seeds resulted in $45 \mathrm{~g}$ of dehulled sprouts (45\%), $19 \mathrm{~g}$ of hulls and $5 \mathrm{~g}$ of rotten and non germinated seeds (Table 1). The main causes of the low yield of dry matter of the de-hulled sprouts are therefore due to the removal of hulls and the high portion of rotten and non germinated seeds. Catabolism of lipids and carbohydrates to produce energy for the germinating seeds may have also contributed to the loss of the dry weight. A similar reduction in yield of sprouts ( $\mathrm{db}$ ) was also found in sprouting of flaxseed where $35 \%$ of dry matter was lost after germination for 8 days [15]. 
Table 1. Yield of ASL during germination.

\begin{tabular}{cccc}
\hline Sample & $\begin{array}{c}\text { Weight of } \\
\text { de-hulled } \\
\text { sprouts }(\mathrm{g}, \mathrm{db})\end{array}$ & $\begin{array}{c}\text { Weight of } \\
\text { hulls }(\mathrm{g}, \mathrm{db})\end{array}$ & $\begin{array}{c}\text { Weight of rotten } \\
\text { and non } \\
\text { germinated }(\mathrm{g}, \mathrm{db})\end{array}$ \\
\hline Day 1 & $63.5 \pm 1.92^{\mathrm{a}}$ & $20.4 \pm 0.68^{\mathrm{a}}$ & $3.5 \pm 0.75^{\mathrm{a}}$ \\
Day 2 & $59.7 \pm 0.48^{\mathrm{ab}}$ & $19.7 \pm 0.09^{\mathrm{a}}$ & $4.9 \pm 2.92^{\mathrm{a}}$ \\
Day 3 & $58.3 \pm 2.79^{\mathrm{abc}}$ & $19.8 \pm 0.81^{\mathrm{a}}$ & $3.3 \pm 3.11^{\mathrm{a}}$ \\
Day 4 & $56.3 \pm 2.05^{\mathrm{bc}}$ & $19.7 \pm 0.77^{\mathrm{a}}$ & $3.9 \pm 0.43^{\mathrm{a}}$ \\
Day 5 & $54.4 \pm 1.78^{\mathrm{bc}}$ & $19.7 \pm 0.74^{\mathrm{a}}$ & $4.7 \pm 2.74^{\mathrm{a}}$ \\
Day 6 & $52.3 \pm 1.69^{\mathrm{cd}}$ & $19.3 \pm 0.53^{\mathrm{a}}$ & $2.5 \pm 0.97^{\mathrm{a}}$ \\
Day 7 & $52.9 \pm 1.98^{\mathrm{d}}$ & $19.8 \pm 0.44^{\mathrm{a}}$ & $2.3 \pm 1.13^{\mathrm{a}}$ \\
Day 8 & $47.6 \pm 2.13^{\mathrm{de}}$ & $19.3 \pm 0.73^{\mathrm{a}}$ & $4.3 \pm 1.59^{\mathrm{a}}$ \\
Day 9 & $44.8 \pm 3.34^{\mathrm{e}}$ & $19.2 \pm 0.65^{\mathrm{a}}$ & $4.5 \pm 2.85^{\mathrm{a}}$ \\
\hline
\end{tabular}

The yields of lupin expressed as dry weight (g/100g lupin seeds) during germination. Results are expressed as means \pm standard deviations of measurements. Different letter in the same column are significantly different $(\mathrm{P}<$ $0.05)$.

\subsection{Chemical Composition of Germinated ASL Flour}

Germination affects protein, crude fibre and lipid contents of ASL (Table 2). Raw ASL seeds had 44\% (db) of protein. The protein content of germinated ASL after 9 days had a trend toward a significant increase $(38 \%, \mathrm{P}=$ $0.05)$ compared to that in the raw seeds. The increase in the protein content of germinated ASL flour compared to the protein content in the raw ASL flour may be a result, at least in part, of the loss of non protein dry matter during the germination. The increase was higher than that found by Dagnia et al. [12] who reported that germination for 6 days of $L$. angustifolius increased the protein content by about $10 \%$. The increase in protein content after germination was also found in other legumes such as soybean [6], mungbean [16], fenugreek [17] and dry bean, lentils, faba beans [18].

Another major chemical component of lupin is lipid, which is a source of nutritional components and bioactive compounds such as mono- and polyunsaturated fatty acids, tocopherols and phytosterols. As shown in Table 2, following germination for 9 days, a significant decline in ASL total lipid content from $6.4 \%$ to $1.9 \%$ ( $70 \%$ decrease) was observed $(\mathrm{P}<0.05)$. This result was higher than that reported by Dagnia et al. [12] who observed that germination of L. angustifolius for 6 days decreased its lipid content by $50 \%$. The decline is likely to be due to the use of the lipid as energy source during germination. Lipid content has also been reported to decrease during germination in soybean [6] and flax seeds [15].

Lupin contains a high content of dietary fibre and this plays an important role in its hypocholesterolemic prop-
Table 2. Protein, fat and crude fibre content during germination.

\begin{tabular}{cccc}
\hline Samples & Protein (\%) & Fat (\%) & Crude fibre (\%) \\
\hline Raw & $44.1 \pm 1.7^{\mathrm{a}}$ & $6.4 \pm 0.1^{\mathrm{a}}$ & $1.6 \pm 0.02^{\mathrm{a}}$ \\
Day 1 & $48.3 \pm 1.6^{\mathrm{b}}$ & $6.7 \pm 0.1^{\mathrm{b}}$ & $2.2 \pm 0.7^{\mathrm{b}}$ \\
Day 3 & $50.4 \pm 1.4^{\mathrm{b}}$ & $4.6 \pm 0.2^{\mathrm{c}}$ & $3.5 \pm 0.3^{\mathrm{c}}$ \\
Day 5 & $54.0 \pm 1.6^{\mathrm{c}}$ & $3.1 \pm 0.3^{\mathrm{d}}$ & $5.4 \pm 0.2^{\mathrm{d}}$ \\
Day 7 & $56.7 \pm 2.1^{\mathrm{c}}$ & $2.3 \pm 0.1^{\mathrm{e}}$ & $7.4 \pm 0.2^{\mathrm{e}}$ \\
Day 9 & $61.0 \pm 2.0^{\mathrm{d}}$ & $1.9 \pm 0.1^{\mathrm{f}}$ & $8.9 \pm 0.3^{\mathrm{f}}$ \\
\hline
\end{tabular}

Protein, fat and crude fibre content during germination expressed on a dry weight basis $(\mathrm{g} / 100 \mathrm{~g}$ DM of de-hulled germinated ASL flour). Values are means \pm standard deviations of measurements. Different letter in the same column indicates a significant difference $(\mathrm{P}<0.05)$.

erties. The crude fibre content during germination in the present study increased by $456 \%$ (approaching significance, $\mathrm{P}=0.05$ ) after 9 days (Table 2 ). In other studies, a high concentration $(36 \%)$ of dietary fibre has been reported in L. albus following germination for 2 days [19]. The effect of germination on dietary fibre has also been studied in peas where it was found that the total dietary fibre increased substantially during germination by about $100 \%$ [20]. This increase in dietary fibre was reported to be mostly due to changes in the polysaccharides found in the cell wall such as cellulose, glucose and mannose, suggesting that the changes were due to an increase in the cellular structure of the plant during germination [20]. Therefore, germination of ASL seeds in the present study appears to be an effective way to improve fibre content in ASL.

\subsection{Protein Isolate from Germinated ASL Flour}

Vegetable proteins have been widely used in food formulations due to their functional properties such as emulsifying activity, emulsion stability and foaming capacity. Protein isolate of germinated ASL flour may exhibit different functional characteristics when compared to protein isolate of raw ASL flour. In this study, proteins in germinated ASL flours were fractionated into protein isolate and soluble fraction. There was a change in yields of protein isolates (approaching significance, $\mathrm{P}=0.05$ ) following germination (Table 3). The yield of protein isolate in the raw ASL flour was $21 \%(\mathrm{db})$ whereas the protein isolate was only $4.7 \%(\mathrm{db})$ following germination for 9 days. The yields of protein in the soluble fraction were also reduced by about $76 \%$ (approaching significance, $\mathrm{P}=0.05)$ at day 9 of germination. These results were in contrast with results of a similar study by Akaerue and Onwuka [21], who found that sprouting of mungbean from 1 day to 2 days results in an increase in protein isolate from $6.6 \%$ to $7.2 \%$ (g protein $/ 100 \mathrm{~g}$ of 
Table 3. Yields of protein isolate and soluble fraction isolated from germinated ASL flours.

\begin{tabular}{ccc}
\hline \multirow{2}{*}{ Samples } & \multicolumn{2}{c}{$\%$ Yields $(\mathrm{db})$} \\
\cline { 2 - 3 } & Protein Isolate & Soluble Fraction \\
\hline Raw & $21.6 \pm 1.8^{\mathrm{a}}$ & $5.9 \pm 1.1^{\mathrm{a}}$ \\
Day 3 & $17.6 \pm 3.8^{\mathrm{ab}}$ & $3.8 \pm 0.03^{\mathrm{b}}$ \\
Day 5 & $14.7 \pm 3.2^{\mathrm{b}}$ & $3.2 \pm 0.33^{\mathrm{c}}$ \\
Day7 & $6.0 \pm 0.5^{\mathrm{c}}$ & $2.1 \pm 0.27^{\mathrm{d}}$ \\
Day 9 & $4.7 \pm 0.4^{\mathrm{d}}$ & $1.4 \pm 0.42^{\mathrm{e}}$ \\
\hline
\end{tabular}

Yields of the protein isolate and the soluble fractions isolated from germinated ASL flour expressed as \% $(\mathrm{g} / 100 \mathrm{~g} \mathrm{db})$. Values are means \pm standard deviations of measurements. Different letter in the same column indicates a significant difference $(\mathrm{P}<0.05)$.

flour) however the discrepancy may be due to the difference in the length of germination. The changes in the yields of the protein isolate due to germination process in this study may influence their functional properties. In another study, germination has been reported to improve functional properties of legumes [22].

\subsection{Protein Composition of Protein Isolate and Soluble Fraction of Germinated ASL Flour Using SDS-PAGE}

Proteins in legume seeds consist of storage proteins, structural proteins and biologically active enzymes. The storage proteins can be categorized into globulins, albumins, prolamins and glutelines. Globulins in lupins consist of $\alpha, \beta, \gamma$ and $\delta$-conglutin [9]. The total protein extracts of lupin can be further fractionated to separate proteins into protein isolate $\mathrm{E}(\alpha, \beta, \delta$-conglutin) and soluble fraction/isolate F ( $\gamma$-conglutin) as reported by Sironi et al. [14].

The profile of proteins extracted from the raw and germinated ASL flour samples were analysed using SDSPAGE. As shown in Figure 1, the proteins present in raw ASL have a molecular weight ranging from $15-90 \mathrm{kDa}$ (lane 1). The major proteins found in legume seed are storage proteins, making up to approximately $75 \%$ of the total protein content [9]. The total protein profile of ASL was dramatically changed by germination after day 3 as shown in lane 3 in Figure 1. In comparison with the previous studies $[23,24]$ and the SDS-PAGE results of protein isolate and soluble fraction, it can be considered that the proteins which have the molecular weights of approximately $19,38,40,46,58,50-65$ and $90 \mathrm{kDa}$ are likely to belong to the subunits of the $\alpha$ and $\beta$ conglutin, whereas proteins with molecular weight of 35, 30 and 19 $\mathrm{kDa}$ are probably polypeptides of $\gamma$-conglutin.

During the germination process, there were some marked changes in the protein composition. For example,

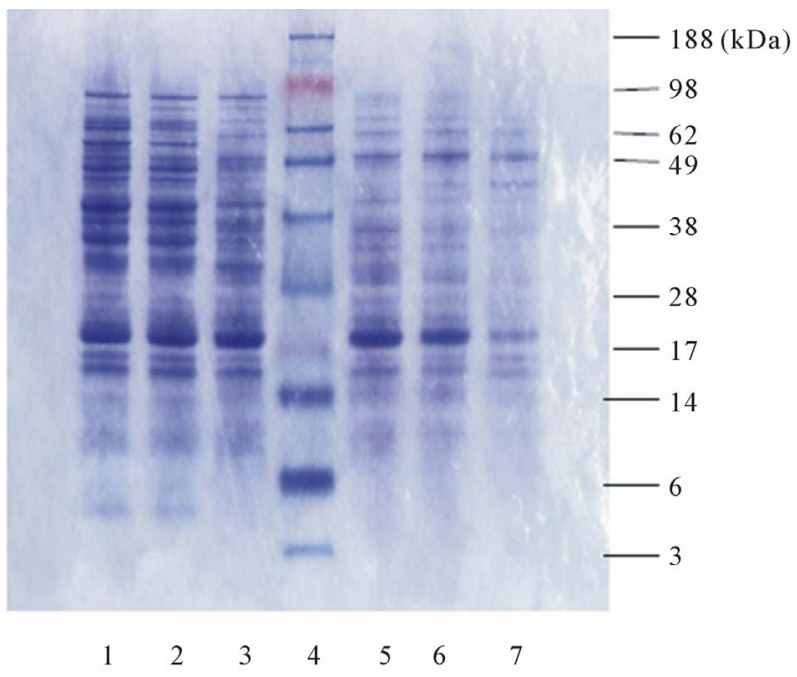

Figure 1. Changes in total protein profile of extracts from germinated ASL flour. The electrophoresis gel shows bands of proteins extracted from germinated ASL flour separated by SDS-PAGE. The following lanes (from left to right) are protein extracts of: 1) Raw seeds; 2) Day 1; 3) Day 3; 4) Protein molecular weight marker; 5) Day 5; 6) Day 7; 7) Day 9. The molecular weights of the protein standards (lane 4) are indicated on the right of the electrophoresis gel.

proteins with molecular weights of around 40,50, 65 and $90 \mathrm{kDa}$ began to disappear at day 5 of germination (Figure 1, lane 5). Whilst, a single band with molecular weight at $46 \mathrm{kDa}$ remained until day 9 of germination (Figure 1, lane 7). Two bands with molecular weight close to $16 \mathrm{kDa}$ were still present following 9 days of germination. Normally during the process of germination, protein breakdown occurs as the plant uses the storage proteins as source of nitrogen and carbon for bio-molecule synthesis [25]. However, there was no evidence of low molecular weight polypeptides being formed during germination. It is therefore suggested that, the high mo- lecular weight of proteins may have broken down to short chain peptides and amino acids which were not detectable under our electrophoretic conditions.

It has been reported that proteins isolated by the same procedure by Sironi et al. [14] were predominantly composed of $\alpha$ and $\beta$ conglutin and the isolate was termed protein isolate E. Whereas the soluble fraction was referred to as protein isolate $\mathrm{F}$ which consists mainly of $\gamma$-conglutin. Figure 2 shows the electrophoresis gels following SDS PAGE to confirm the proteins present in protein isolate and soluble fraction. As shown in Figure 2, polypeptides of protein isolate which may be $\alpha$ and $\beta$ conglutin with molecular weight of around 50, 40 and 19 $\mathrm{kDa}$ diminished following germination for more than 3 days. These results are in agreement with the previous results of SDS PAGE for total proteins (Figure 1). Furthermore, the bands with MW of 30,19 and $16 \mathrm{kDa}$ may 


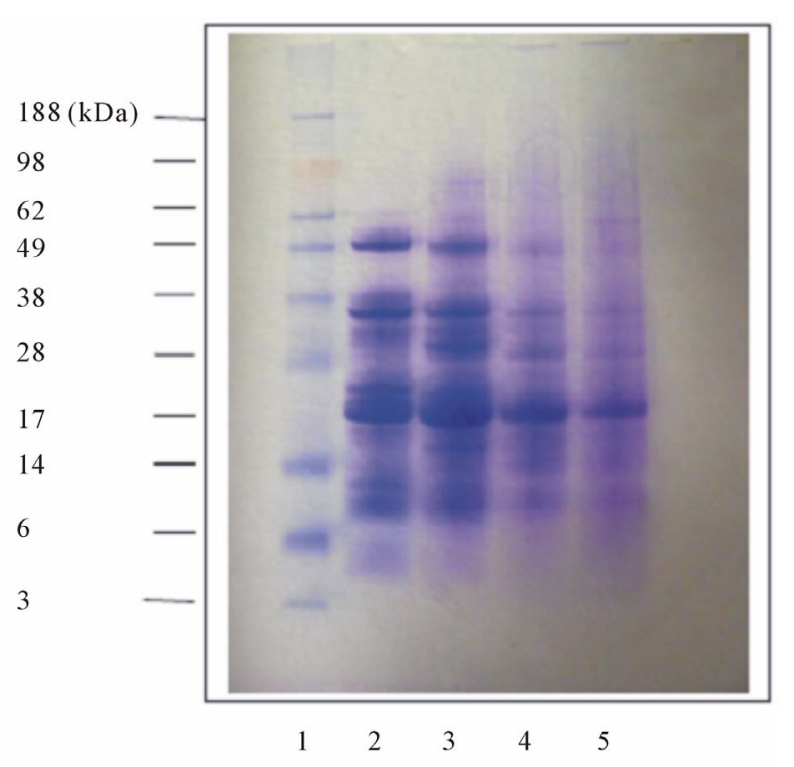

(a)

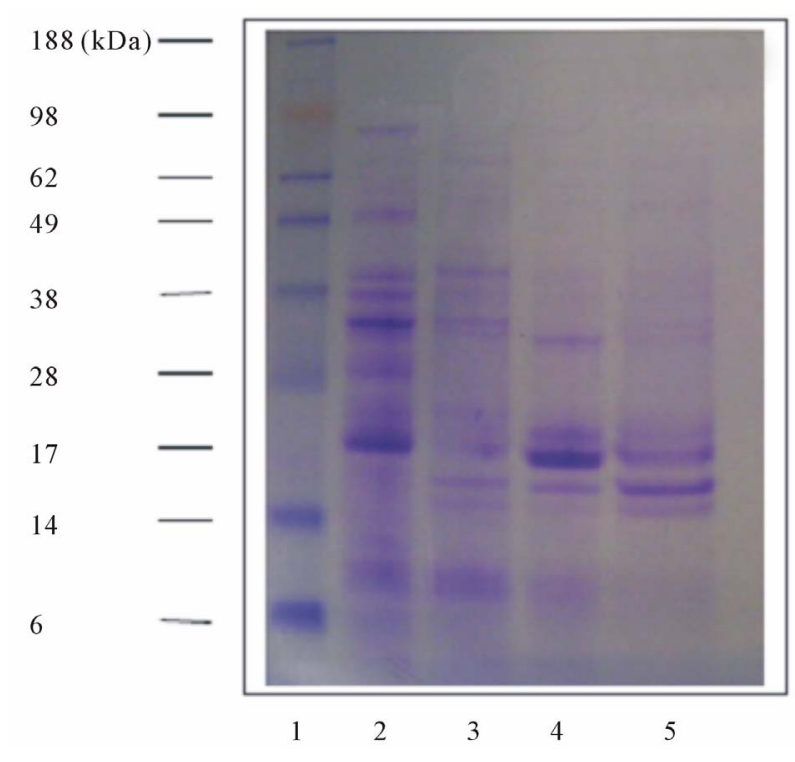

(b)

Figure 2. Changes in the protein profile of protein isolate (a) and soluble fraction (b) from germinated ASL flour. The electrophoresis gel shows bands of the protein isolate (a) and soluble fraction (b) from germinated ASL flour separated using SDS-PAGE. The following lanes (from left to right) are: 1) Protein molecular weight marker; 2) Raw seeds; 3) Day 3; 4) Day 7; 5) Day 9. The molecular weights of the protein standards (lane 1) are indicated on the left of electrophoresis.

be $\gamma$ - conglutin and a low molecular weight protein present in the soluble fraction (Figure 2).

The change in composition of protein isolates and soluble fraction of germinated ASL flour could affect the functional properties of the protein isolates. As reported by Lqari et al. [26], different composition of protein iso- lates of L. angustifolius isolated with different methods had different functional properties. The increased fibre and decreased fat content of germinated ASL flour make it an ideal food ingredient for incorporation in human diet. The breakdown of proteins of ASL during germination process may affect the yield of protein isolate and protein composition which may affect its functional properties.

\section{Conclusion}

The results of this study suggest that germination represents an attractive, inexpensive means of improving the nutritional profile of lupin flour. Importantly an increase in the fibre, but decrease in the lipid content would improve the nutritional profile of foods incorporated with germinated lupin flour. The changes in protein profile in germinated ASL flour possibly affect the functional properties of the protein. However further characterisation of the protein profile and the suitability and acceptability of germinated lupin flour for incorporation into a range of food products remains to be determined.

\section{Acknowledgements}

Authors are grateful to have been awarded the Endeavour International Postgraduate Research Scholarship (EIPRS) and Curtin Postgraduate Award (CUPS) which assisted greatly in the $\mathrm{PhD}$ project of Rumiyati. Authors also thank the Centre for Food \& Genomic Medicine (CFGM) for support of this project.

\section{REFERENCES}

[1] V. Jayasena and K. Quail, "Lupin: A Legume with A Future," Food and Beverage Asia, Vol. 12, 2004, pp. 16-22.

[2] C. D. L. Cuadra, M. Muzquiz, C Burbano, G. Ayet, R. Calvo, A. Osagie and C. Cuadrado, "Alkaloid, $\alpha$-Galactoside and Phytic Acid Changes in Germinating Lupin Seeds," Journal of the Science of Food \& Agriculture, Vol. 66, No. 3, 1994, pp. 357-364. doi:10.1002/jsfa.2740660313

[3] R. G. Ruiz, K. R. Price, M. E. Rose, A. E. Arthur, D. S. Petterson and R. Fenwick, "The Effect of Cultivar and Environment on Saponin Content of Australian Sweet Lupin seeds," Journal of the Science of Food \& Agriculture, Vol. 69, No. 3, 1995, pp. 347-351. doi:10.1002/jsfa.2740690311

[4] V. Jayasena, H. J. Chih and S. M. Nasar-Abbas, "Functional Properties of Sweet Lupin Protein Isolated and Tested at Various pH Levels," Research Journal of Agriculture \& Biological Science, Vol. 6, No. 2, 2010, pp. 130-137.

[5] D. Zhu, N. S. Hettiarachchy, R. Horax and P. Chen, "Isoflavone Contents in Germinated Soybean Seeds," Plant Foods for Human Nutrition, Vol. 60, No. 3, 2005, 


\section{pp. 147-151. doi:10.1007/s11130-005-6931-0}

[6] M. M. Mostafa and E. H. Rahma, "Chemical and Nutritional Change in Soybean during Germination," Food Chemistry, Vol. 23, No. 4, 1987, pp. 257-275. doi:10.1016/0308-8146(87)90113-0

[7] C. Martinez-Villaluenga, P. Gulewicz, J. Frias, K. Gulewicz and C. Vidal-Valverde, "Assessment of Protein Fractions of Three Cultivars of Pisum sativum L.: Effect of Germination," European Food Research \& Technology, Vol. 226, No. 6, 2008, pp. 1465-1478. doi:10.1007/s00217-007-0678-9

[8] E. Sangronis and C. J. Machado, "Influence of Germination on the Nutritional Quality of Phaseolus vulgaris and Cajanus cajan," LWT-Food Science \& Technology, Vol. 40, No. 1, 2007, pp. 116-120.

[9] M. Duranti, A. Consonni, C. Magni, F. Sessa and A. Scarafoni, "The Major Proteins of Lupin Seed: Characterization and Molecular Properties for Use as Functional and Nutraceutical Ingredients," Trends in Food Science \& Technology, Vol. 19, No. 12, 2008, pp. 624-633. doi:10.1016/j.tifs.2008.07.002

[10] M. M. Morad, H. K. Leung, D. L. Hsu and P. L. Finney, "Effect of Germination on Physicochemical and BreadBaking Properties of Yellow Pea, Lentil and Faba Bean Flours and Starches," Cereal Chemistry, Vol. 57, No. 6, 1980, pp. 390-396.

[11] A. Torres, J. Frias, M. Granito and C. Vidal-Valverde, "Germinated Cajanus cajan Seeds as Ingredients in Pasta Products: Chemical, Biological and Sensory Evaluation," Food Chemistry, Vol. 101, No. 1, 2007, pp. 202-211. doi:10.1016/j.foodchem.2006.01.018

[12] S. G. Dagnia, D. S. Petterson, R. R. Bell and F. V. Flanagan, "Germination Alters the Chemical Composition and Protein Quality of Lupin Seeds," Journal of Science \& Food Agriculture, Vol. 60, No. 4, 1992, pp. 419- 423. doi:10.1002/jsfa.2740600403

[13] AOAC, "Official Methods of Analysis of AOAC International," AOAC International, Gaithersburg, 2000.

[14] E. Sironi, F. Sessa and M. Duranti, "A Simple Procedure of Lupin Seed Protein Fractionation for Selective Food Applications," European Food Research \& Technology, Vol. 221, No. 1-2, 2005, pp. 145-150. doi:10.1007/s00217-005-1151-2

[15] P. K. J. P. D. Wanasundara, U. N. Wanasundara, F. Shahidi, "Changes in Flax (Linum usitatissimum L.) Seed Lipids during Germination," Journal of American Oil Chemistry Society, Vol. 76, No. 1, 1999, pp. 41-48. doi:10.1007/s11746-999-0045-Z

[16] A. E. Mubarak, "Nutritional Composition and Antinutritional Factors of Mung bean Seeds (Phaseolus aureus) as Affected by Some Home Traditional Processes," Food
Chemistry, Vol. 89, No. 4, 2005, pp. 489-495. doi:10.1016/j.foodchem.2004.01.007

[17] A. El-Mahdy and L. El-Sebaiy, "Effect of Germination on the Nitrogenous Constituents, Protein Fractions, in vitro Digestibility and Antinutritional Factors of Fenugreek Seeds (Trigonella foenum graecum L.)," Food Chemistry, Vol. 8, No. 4, 1982, pp. 253-262. doi:10.1016/0308-8146(82)90027-9

[18] D. Hsu, H. Leung, P. Finney and M. Morad, "Effect of Germination on Nutritive Value and Baking Properties of Dry Peas, Lentils, and Faba Beans," Journal of Food Science, Vol. 45, No. 1, 1980, pp. 87-92. doi:10.1111/j.1365-2621.1980.tb03877.x

[19] L. C. Trugo, C. M. Donangelo, N. M. F. Trugo and K. E. B. Knudsen, "Effect of Heat Treatment on Nutritional Quality of Germinated Legume Seeds," Journal of Agriculture \& Food Chemistry, Vol. 48, No. 6, 2000, pp. 2082-2086. doi:10.1021/jf9913920

[20] M. Martin-Cabrejas, N. Ariza, R. Esteban, E. Molla, K. Waldron and F. Lopez-Andreu, "Effect of Germination on the Carbohydrate Composition of the Dietary Fiber of Peas (Pisum sativum L.)," Journal of Agriculture \& Food Chemistry, Vol. 51, No. 5, 2003, pp. 1254-1259. doi:10.1021/jf0207631

[21] B. I. Akaerue and G. I. Onwuka, "Evaluation of the Yield, Protein Content and Functional Properties of Mungbean [Vigna radiata (L.) Wilczek] Protein Isolates as Affected by Processing," Pakistan Journal of Nutrition, Vol. 9, No. 8, 2010, pp. 728-735. doi:10.3923/pjn.2010.728.735

[22] R. A. Ghavidel and J. Prakash, "Effect of Germination and Dehulling on Functional Properties of Legume Flours," Journal of Science \& Food Agriculture, Vol. 86, 2006, pp. 1189-1195. doi:10.1002/jsfa. 2460

[23] T. S. Melo, R. B. Ferreira, A. N. Teixeira, "The Seed Storage Proteins from Lupinus albus," Phytochemistry, Vol. 37, No. 3, 1994, pp. 641-648. doi:10.1016/S0031-9422(00)90331-5

[24] C. N. Santos, R. B. Ferreira and A. R. Teixeira, "Seed Proteins of Lupinus mutabilis," Journal of Agriculture Food \& Chemistry, Vol. 45, No. 10, 1997, pp. 3821-3828. doi:10.1021/jf970075v

[25] M. Duranti, E. Cucchetti and P. Cerletti, "Change in Composition and Subunits in the Storage Protein of Germinating Lupin Seeds," Journal of Agriculture Food \& Chemistry, Vol. 32, No. 3, 1984, pp. 490-493. doi:10.1021/jf00123a018

[26] H. Lqari, J. Vioque, J. Pedroche and F. Millán, “Lupinus angustifolius Protein Isolates: Chemical Composition, Functional Properties and Protein Characterization," Food Chemistry, Vol. 76, No. 3, 2002, pp. 349-356. doi:10.1016/S0308-8146(01)00285-0 